技術紹介

歯肉ラインを整える審美補綴法（BTA テクニック）の開発

坪田 健嗣

\title{
Development of an Esthetic Prosthetic Technique (the BTA Technique) for Aligning the Gingival Line
}

\author{
Kenji Tsubota, DDS, PhD
}

抄 録

目的：歯肉剥離や骨削除を伴う大掛かりな外科手術や矯正治療を行わずに，歯肉ラインを整え，後戻りも せず，長期的に歯肉を健康に維持できる審美補綴法，Biological Tissue Adaptation Technique（BTA テ クニック）の開発

治療法：（1）審美的な観点及び，biologic width を考慮し，設定した歯肉ラインの位置で電気メスを用い 歯肉切除を行う。（2）支台歯形成のフィニッシュラインは歯肉切除をした高さにする。 その後印象採得を 行う。（3）補綴装置（ラミネートベニア，クラウン）は，マージン部を歯面にほぼ直角に立ち上げ，歯肉 創面とほぼ同じ厚みで作製し装着する。

考察：本法を 17 症例実施し，経過観察したところ，歯肉ラインの位置が切端方向に後戻りせず，特に大 きな問題もなく歯肉の健康も維持できることが認められた。

その成功の理由として, 健康な歯肉の条件となる biologic width を 3 次元的に維持でき, 歯肉辺縁組織が 補経装置マージンに適合（密着）し陌間がなくなることで, 歯垢の沈着を防ぎ, 健康な歯肉が保たれるの ではないかと思われる。また，歯肉の厚みが保たれ血流が良くなることで生物学的に有利な環境が作られ るものと推察する.

結論：BTA テクニックは，主に補綴的手法により歯肉ラインを整える（根尖方向に移動）治療法として多 くの利点を有し，長期的にも審美性と歯肉の健康を維持することができる.

和文キーワード

歯肉ライン, 歯肉切除, 生物学的幅径, オーバーハング, 審美性

\section{I．緒言}

審美的な補綴を行う際に歯肉ラインを左右対称に整 えることは重要な要件であるが（図 la, b)，単に歯肉 切除を行ない補綴装置を装着した場合には, biologic width の再構築により, 歯肉ラインは後戻りしてもと の位置に戻ってしまうことが多い ${ }^{1)}$ (図 2a). そのため, 歯肉ラインを根尖方向に移動させたい場合には，矯正 治療を行うか, biologic width (生物学的幅径) ${ }^{2,3)}$ を 維持するために歯肉剥離，骨削除を伴う外科手術（歯 冠延長術） ${ }^{4-6)}$ が必要となり，患者の負担が大きい.
そこで今回，大掛かりな外科的な手法に頼らず，主 として補綴的な手法により歯肉ラインを整えることが できる治療法を開発し，長期的に観察を行なった。そ の結果, 歯肉ラインは後戻りすることなく審美性を保 ち，歯肉の健康も維持できることが確認できたので報 告する.

\section{II．治療法}

電気メスを用い歯肉切除を行い, 同位置にフィニッ シュラインとした形成を行い，印象採得を行う。補綴装 置（本症例ではラミネートベニア）は，マージン部を歯

フォーラムデンタルクリニック

Forum Dental Clinic

受付 : 2008 年 11 月 13 日/受理 : 2009 年 9 月 9 日

Received on November 13, 2008/Accepted on September 9, 2009 
a

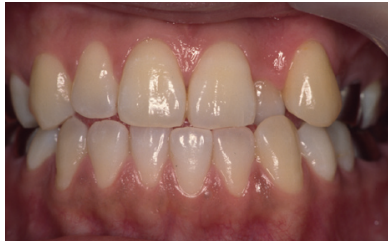

b

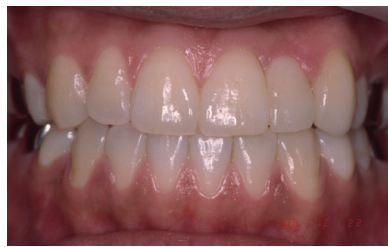

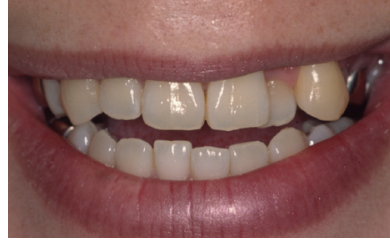

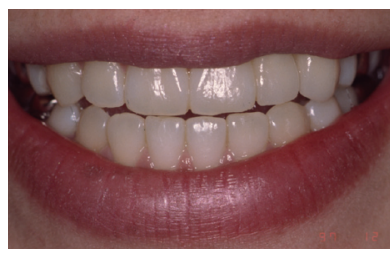

図 1 The symmetrical gingival line is important for esthetic prosthesis.

a: The unsymmetrical gingival line before treatment

b: The symmetrical gingival line after treatment 歯肉ラインの左右の対称性は, 審美補綴を行う際 に，重要である。

$\mathrm{a}:$ 術前の左右不対称の歯肉ライン

$\mathrm{b}:$ 術後の左右対称の歯肉ライン

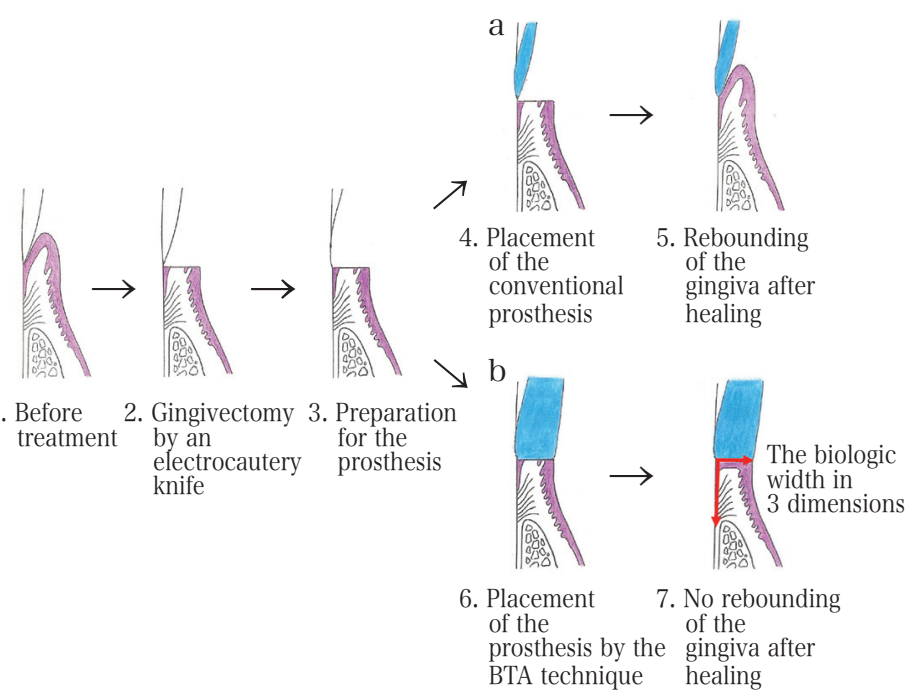

図 2 The shape of the margin of the prosthesis a: Conventional prosthesis with normal shape of the margin

b: Prosthesis by the BTA technique 補綴装置のマージン部形態

$\mathrm{a}$ : 通常のマージン形態の補綴装置

b: BTA テクニックによる補綴装置

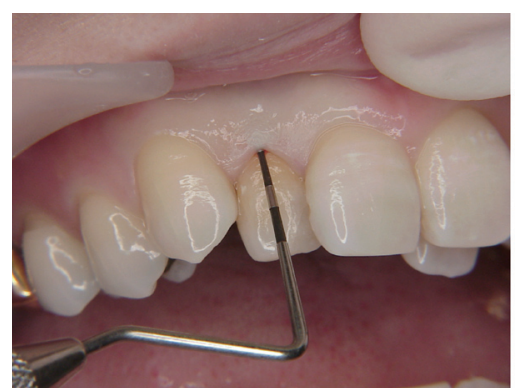

面にほぼ直角に立ち上げ，歯肉創面とほぼ同じ厚みで作 製し装着する。すなわち，唇側マージン部はオーバーハ ングとなる(図 $2 \mathrm{~b})$.

\section{1. 電気メスによる歯肉切除}

審美的な観点及び biologic width を考慮し，設定した 歯肉ラインの位置で, 電気メスを用いて歯肉切除を行う. なお，biologic width を維持するためには，あらかじめ ボーンサウンディングにより，骨緑の位置を診査してお く必要がある(図 3)。

\section{2. 支台歯形成，印象}

唇側の支台歯形成は，基本的には，歯肉切除を行った 位置と同じ位置にフィニッシュラインを設定し，形成を 行う。印象は止血を確実に行ってから行う（図 4).

\section{3. プロビジョナルレストレーションの作製法}

プロビジョナルレストレーションは, 歯肉切除を行っ た歯肉辺縁部で，切端側方向に後戻りしないように，歯 肉に接触させ，歯肉とほぼ同じ厚みに作製する。本症例 では，口腔内で直接コンポジットレジンを築盛して作製 した。歯肉との接触部の研磨は行なっていない.

\section{4. ラミネートベニアの作製方法}

歯肉切除を行った唇側では，ラミネートベニアのマー
ジンは，歯面にほぼ直角に立ち上げ，歯肉創面とほぼ同 じ厚みで作製する（図 5)。

\section{5. ラミネートベニア装着}

通法に従って,ラミネートベニアの装着を行う（図 6). その際には，ラミネートベニアのマージンと歯肉との間 にセメントが残らないように注意する。 


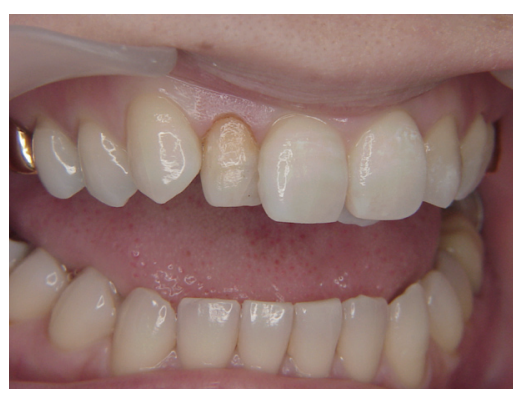

図 4 Gingivectomy and Preparation

In consideration of the esthetic point of view and the biologic width, a $1 \mathrm{~mm}$ gingivectomy was performed to remove of the gingival margin by electrocautery knife.

After that, the impression was taken. The tooth was not almost injured.

歯肉切除と支台歯形成

歯肉ラインの審美性，ならびに Biologic Width を 考慮し, 電気メスにより約 $1 \mathrm{~mm}$ 歯肉切除を行い, 印象彩得を行った。ほとんど，歯は削っていない。
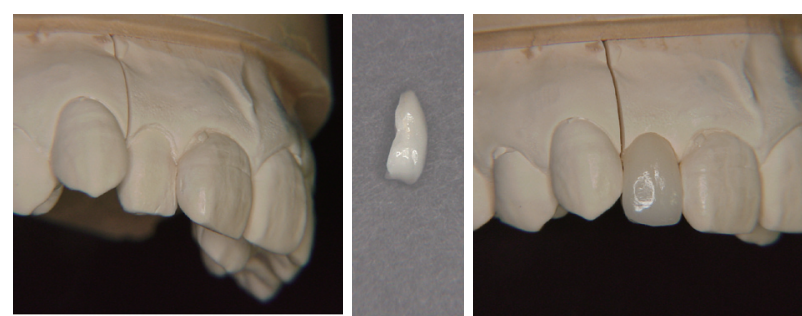

図 5 Forming of the prosthesis

The margin of the laminateveneer was made at a right angle at the surface of the tooth with the same thickness as the gingival tissue.

ラミネートベニアの作製

ラミネートベニアの唇側マージン部は，歯肉と同 じ厚み (約 $1 \mathrm{~mm}$ ) で歯面にほぼ直角に立ち上げ 作製した。

a
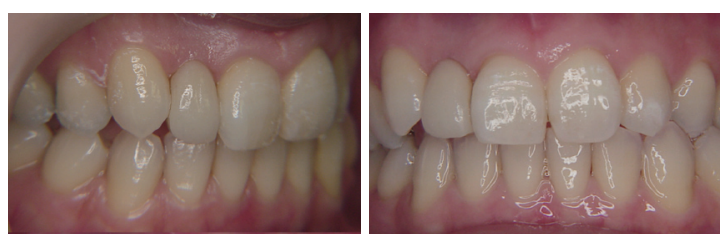

症例 1

患者 : 43 歳, 女性

初診: 平成 15 年 4 月 3 日

主訴：上の前歯をきれいにしたい，歯の色，歯並びが 気になる。

所見：上顎右側 1 番には, 継続歯が装着されており, 歯頝部に黒く変色が認められる。上顎右側 2 番は, 舌 側に転位し反対咬合となっており，歯肉ラインは上顎左 側 2 番に比較して, 約 $1.5 \mathrm{~mm}$ 切端側に位置している（図 7a).

治療経過：上顎右側 1 番は, 継続歯を除去し，ファ イバーポスト併用レジンコアにて築造後, 通法通り, オー ルセラミッククラウンを装着した。舌側転位をしていた 上顎右側 2 番は，整った歯列に見えるように，厚みの あるラミネートベニアを装着することにした。

ただし，上顎右側 2 番の歯肉ラインを根尖方向に移 動しなければ, 歯肉ラインの左右の対象性を改善できず, その上，歯冠長が短く唇側傾斜し，審美的な補経はでき ないものと判断した.

そこで，歯肉ラインを根尖方向に移動するために， BTA テクニックを用い, 約 $1.5 \mathrm{~mm}$ の歯肉切除を行っ た後に，厚みのあるラミネートベニアを装着した。

舌側転移を治す際に, BTA テクニックを用いること で，上顎右側 2 番の歯肉ラインは，根尖側に約 $1.5 \mathrm{~mm}$ 移動できたのと同時に，唇側方向に約 $1.0 \mathrm{~mm}$ 移動し たことで，歯䅡部から切端部にかけての唇側傾斜を緩や
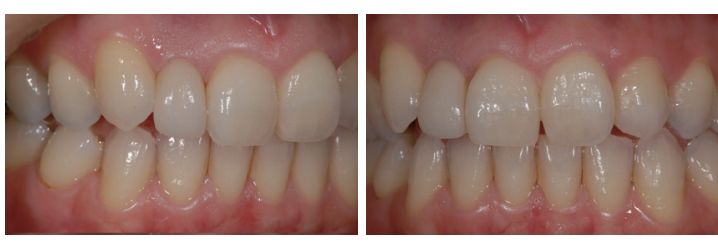

図 6

a: Just after the placement of a laminateveneer b: At 28 months after treatment

The esthetics and the gingival health is maintained.

a: ラミネートベニア装着直後

b: 術後 28 力月

審美性と歯肉の健康はたもたれている。 7b).

術後 64 力月の状態は，歯肉に炎症は認められず，歯 肉ラインの後戻りや歯肉退縮もなく，良好な審美性と歯 肉の健康を保ち, エックス線写真の診査でも, 治療前と 比較して骨吸収は認められなかった（図 7c)。

\section{症例 2}

患者 : 43 歳, 女性

初診：平成 10 年 12 月 9 日

主訴：前歯の歯並びを整えたい。特に上の 2 番目の
かにし, 自然で審美的な形態に見せることができた（図 
a
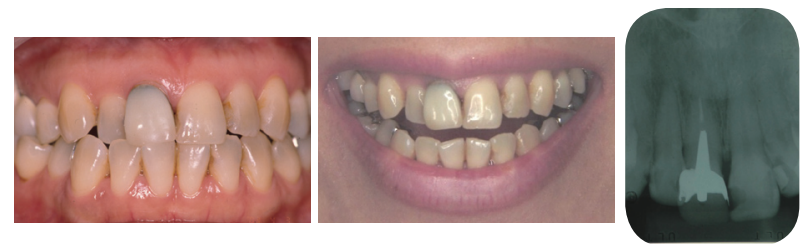

$\mathrm{b}$
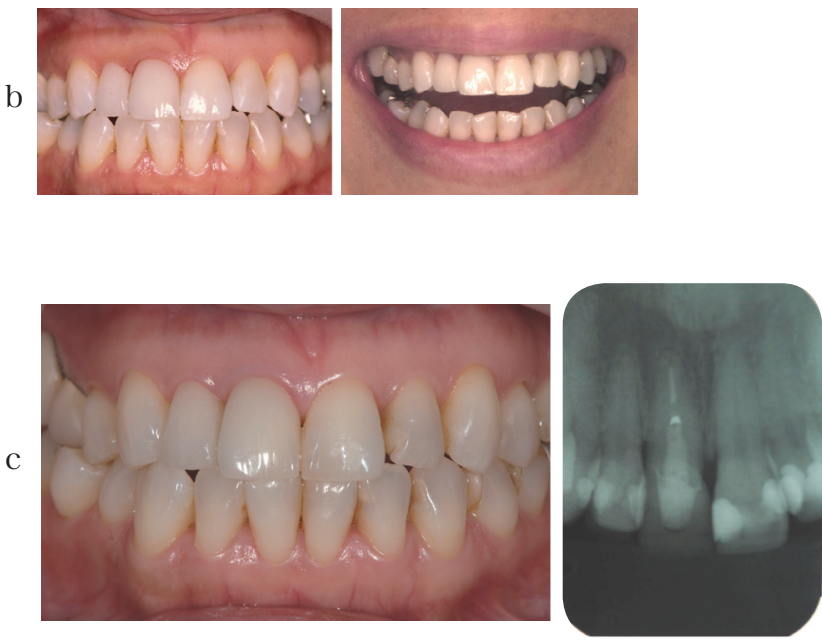

図 7

Case No.1

Laminateveneer was placed after $1.5 \mathrm{~mm}$ gingivectomy using electrocautery knife on the upper right 2nd incisor by the BTA technique. At 64 month after treatment the gingiva has not rebounded and remains healthy.

a: Before treatment, b: Just after treatment, c: At 64 month after treatment

症例 1

上顎右側 2 番に, BTA テクニックにより, 電気メ スで約 $1.5 \mathrm{~mm}$ の歯肉切除を行い, ラミネートべ ニアを装着した。術後 64 力月において，歯肉ラ インは後戻りせず，健康を維持している。 また， エックス線写真から，骨吸収は認められない。

a: 術前, b: 術直後, c: 術後 64 力月 a
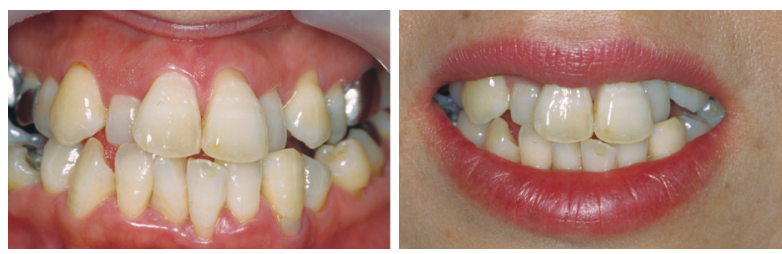

$\mathrm{b}$
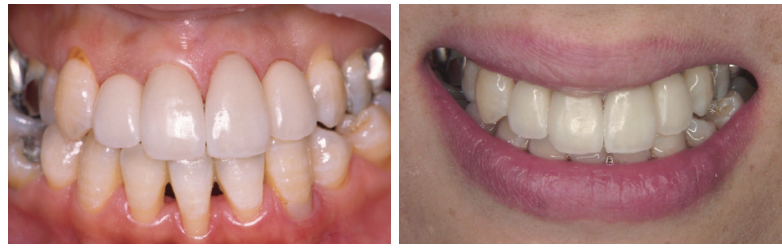

$\mathrm{c}$
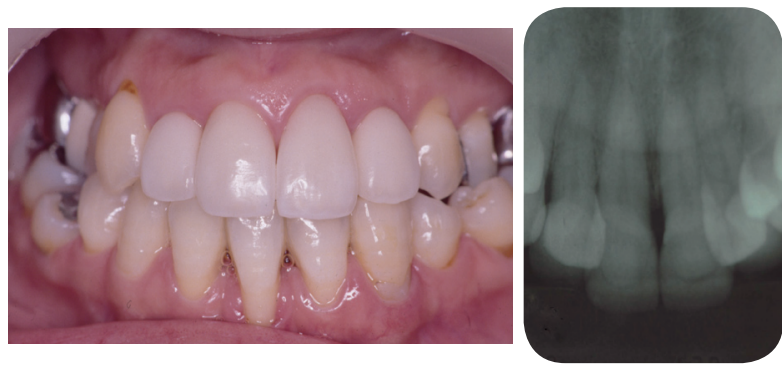

図 8

Case No.2

Laminateveneers were placed after $2 \mathrm{~mm}$ gingivectomy on the upper right 2 nd incisor and $1 \mathrm{~mm}$ gingivectomy on the upper left 2nd incisor by electrocautery knife by the BTA technique. At 6 years after treatment the gingiva has not rebounded and remains healthy.

a: Before treatment, b: Just after treatment, c: At 6 years after treatment

症例 2

上顎両側 2 番に，BTA テクニックにより，電気メ スにて右側は約 $2 \mathrm{~mm}$, 左側は約 $1 \mathrm{~mm}$ の歯肉切 除を行い，ラミネートベニアを装着した。術後 6 年において，歯肉ラインは後戻りせず，健康を維 持している。病的な骨吸収も認められない. a: 術前, b: 術直後, c: 術後 6 年

向に移動しなければ，歯冠長が短く唇側傾斜をしてしま うため，審美的な補綴はできないものと判断した。

そこで，歯肉ラインを根尖方向に移動するために， BTA テクニックを用い，上顎右側 2 番には，約 2.0 $\mathrm{mm}$, 上顎左側 2 番には, 約 $1.0 \mathrm{~mm}$ の歯肉切除を行っ た後に，厚みのあるラミネートベニアを装着した。

舌側転移を治す際に，BTA テクニックを用いること で，唇側傾斜を防ぐことができ，審美的な補経を行うこ とができた（図 8b).

術後約 6 年の状態は, 歯肉に炎症は認められず, 歯肉ラインの後戻りや歯肉退縮もなく，良好な審美
上顎両側側切歯は，舌側転移を治すために，ラミネー トベニアを装着することにしたが，歯肉ラインを根尖方 
性と歯肉の健康を保っている。エックス線写真によ る診査でも, 病的な骨吸収, 齸蝕は認められなかっ た (図 8c).

\section{III. 本法の新規性}

歯肉ラインを整える（根尖方向に移動する）場合は, 通常，矯正治療や歯肉剥離，骨削除を伴う外科的手法 （歯冠延長手術）が必要となるため, 治療期間が長く なり, 患者の負担が大きい. また, 単に歯肉切除を行 ないクラウンを装着した場合は，後戻りをすることが 多い.

BTA テクニックでは, 歯肉切除後の辺縁歯肉をオー バーハングの形態をしたクラウンマージンで抑えるこ とで後戻りを防止でき, 歯肉の健康も保つことができる.

すなわち, BTA テクニックは, 矯正治療や大掛かり な外科的な手法に頼らず，補綴的な手法により歯肉ラ インを整えることができる点で, 新規性があるものと 思われる。

\section{IV. 考 察}

今回, BTA テクニックを用いて, クラウン 3 症例, ラミネートベニア 14 症例の計 17 症例の経過観察を行つ た（表 1). 経過観察の期間は平均で 50.4 力月であり, 21 力月から 126 カ月であった.

今回提示した症例のうち, 歯肉辺緑に発赤が認められ たものは 1 症例もなかった。プロービングの際に，出 血を確認したものは 3 症例あったが，重篤な炎症を引 き起こしていたものは, 1 症例も認められなかった.

また, 症例 1 と症例 2 のックス線写真を診査しても, 骨吸収は認められなかった。

歯肉退縮, 歯肉の後戻りに関しては, 術直後と術後の 経過観察時の写真を肉眼的に比較したが，1症例も歯肉 退縮，歯肉の後戻りは認められなかった。

歯肉ラインを整えるために, 通常, 矯正治療, 歯冠延 長手術が行われているが，両方とも治療期間が長く，患 者の肉体的, 精神的, 経済的な負担は大きい. 歯科医師 にとっては，矯正，歯周外科手術に関する専門的に高度 な知識と技術が要求される。なお，それぞれの術式には 大きな欠点や問題点がある。

矯正治療の場合には，時間が経過することで，可徹式 のリテーナーを使用した場合には, 歯の位置が後戻りし てしまうことが頻繁に起こる。補綴装置を使って固定を する場合には，その問題は解決されるが，本来，必要の ない歯に対してもクラウンが必要になったり，プラーク
表 1 Results of the follow-up examination of the esthetic prosthesis by the BTA technique BTA テクニックによる審美補綴の観察結果

\begin{tabular}{|c|c|c|c|c|c|c|c|}
\hline $\begin{array}{l}\text { Subject } \\
\text { No. }\end{array}$ & $\begin{array}{l}\text { Tooth } \\
\text { No. }\end{array}$ & $\begin{array}{c}\text { Type of } \\
\text { prosthesis }\end{array}$ & $\begin{array}{c}\text { Patient's } \\
\text { age }\end{array}$ & $\begin{array}{l}\text { Follow-up } \\
\text { period } \\
\text { (month) }\end{array}$ & $\begin{array}{c}\text { Red } \\
\text { marginal } \\
\text { gingiva* }\end{array}$ & $\begin{array}{l}\text { Bleeding } \\
\text { on } \\
\text { probing* }\end{array}$ & $\begin{array}{l}\text { Rebound \& } \\
\text { recession** }\end{array}$ \\
\hline 1 & 10 & $\begin{array}{l}\text { All-ceramic } \\
\text { crown }\end{array}$ & 25 & 126 & - & - & - \\
\hline 2 & 10 & $\begin{array}{l}\text { All-ceramic } \\
\text { crown }\end{array}$ & 37 & 36 & - & - & - \\
\hline 3 & 7 & $\begin{array}{l}\text { Ceramo- } \\
\text { metal crown }\end{array}$ & 36 & 25 & - & - & - \\
\hline 4 & 10 & $\begin{array}{l}\text { Ceramic } \\
\text { laminate } \\
\text { veneer }\end{array}$ & 30 & 54 & - & - & - \\
\hline 5 & 7 & $\begin{array}{l}\text { Ceramic } \\
\text { laminate } \\
\text { veneer }\end{array}$ & 27 & 88 & - & + & - \\
\hline 6 & 7 & $\begin{array}{l}\text { Ceramic } \\
\text { laminate } \\
\text { veneer }\end{array}$ & 43 & 64 & - & - & - \\
\hline 7 & 7 & $\begin{array}{l}\text { Ceramic } \\
\text { laminate } \\
\text { veneer }\end{array}$ & 44 & 72 & - & - & - \\
\hline 8 & 10 & $\begin{array}{l}\text { Ceramic } \\
\text { laminate } \\
\text { veneer }\end{array}$ & 44 & 72 & - & - & - \\
\hline 9 & 8 & $\begin{array}{l}\text { Ceramic } \\
\text { laminate } \\
\text { veneer }\end{array}$ & 25 & 48 & - & - & - \\
\hline 10 & 7 & $\begin{array}{l}\text { Ceramic } \\
\text { laminate } \\
\text { veneer }\end{array}$ & 25 & 48 & - & - & - \\
\hline 11 & 9 & $\begin{array}{l}\text { Ceramic } \\
\text { laminate } \\
\text { veneer }\end{array}$ & 25 & 48 & - & - & - \\
\hline 12 & 8 & $\begin{array}{l}\text { Ceramic } \\
\text { laminate } \\
\text { veneer }\end{array}$ & 36 & 31 & - & - & - \\
\hline 13 & 9 & $\begin{array}{l}\text { Ceramic } \\
\text { laminate } \\
\text { veneer }\end{array}$ & 36 & 31 & - & - & - \\
\hline 14 & 7 & $\begin{array}{l}\text { Ceramic } \\
\text { laminate } \\
\text { veneer }\end{array}$ & 34 & 36 & - & + & - \\
\hline 15 & 10 & $\begin{array}{l}\text { Ceramic } \\
\text { laminate } \\
\text { veneer }\end{array}$ & 34 & 36 & - & + & - \\
\hline 16 & 8 & $\begin{array}{l}\text { Ceramic } \\
\text { laminate } \\
\text { veneer }\end{array}$ & 33 & 21 & - & - & - \\
\hline 17 & 9 & $\begin{array}{l}\text { Ceramic } \\
\text { laminate } \\
\text { veneer }\end{array}$ & 33 & 21 & - & - & - \\
\hline
\end{tabular}

*The red marginal gingiva and bleeding on probing were examined at the follow-up appointment several months after final restoration for each case

** Rebound and recession were evaluated by visually comparing two sets of photographs for each case, one taken immediately after final restoration and another taken at the follow-up appointment several months after final restoration

コントロールが難しくなるという欠点がある.

歯冠延長手術は, biologic width を保つために, 歯肉 剥離と骨削除を必要とし，歯周組織に対するダメージが 大きく，そのために患者の肉体的，精神的な負担も大き い. また，歯肉の厚みが大きい症例では，歯肉の後戻り が起こることも，予想できる。

BTA テクニックは, 従来のクラウンのマージン形態 から,かなりかけ離れたものであり,一見するとオーバー ハングの不良補綴装置のように見えるが，長期的に，歯 肉の健康と審美性を維持することができた。

その理由について, 考察を行う。 


\section{1. biologic width が維持される条件}

biologic width が維持されるためには, 歯肉縁から 骨縁までの距離を $3 \mathrm{~mm}$ 以上とすることが，求められ る ${ }^{2,3)}$. そのため, 歯肉切除により歯肉縁を根尖方 向に移動する際に, 切除後, 歯肉縁から骨縁までの距 離が $3 \mathrm{~mm}$ に満たない場合には，骨を切除し骨縁の位 置を $3 \mathrm{~mm}$ とする必要がある ${ }^{4-6)}$.

骨切除を行わない場合には, biologic width を回復さ せるために，歯肉は後戻りすることが多い ${ }^{1)}$.

しかし，今回提示した症例では，術後，後戻りをした ものは, なかった。

BTA テクニックでは, クラウンマージン部を厚くす ることにより, 歯肉の後戻りを物理的に抑えているが, 骨縁から歯肉縁までの距離を直線的にではなく，3 次元 的に $3 \mathrm{~mm}$ 以上とし, biologic width が維持されている 可能性もある.

BTA テクニックは，3次元的に距離を作るという目 的で，インプラント補綴におけるプラットホームスイッ チング ${ }^{7,8)}$ の考え方と似たところがある. プラットホー ムスイッチングは，インプラントフィクスチャーよりも 径の細いアバットメントを装着することで， 3 次元的に 距離を作り骨の吸収や歯肉退縮を防ぐために行うもの であり, 最近ではコンセンサスの得られた方法となって いる.

2. オーバーハングのマージン形態でも, 歯肉に問 題が起こらない理由

通常，オーバーハングのクラウンマージンは，プラー クの停滞, プラーク除去の難易度から, 不適切であるこ とは言うまでもないが, 今回提示した症例では, 歯肉の 炎症が起きなかった。

BTA テクニックによるラミネートベニアは, オーバー ハングの形態はしているが, 歯肉との接触状態から考え るとエマージェンスアングルが約 90 度となった, 歯肉 縁下の極端なオーバーカントゥアという見方ができる のではないだろうか?

1）歯肉縁下における極端なオーバーカントゥアの歯 肉への影響

歯肉縁下のカントゥア (sub-gingival contour) につ いては，(1) straight（直線的）にする，(2) convex（凸 状）にする，の 2 つ考え方がある.

（1） sub-gingival contour を straight（直線的）にす る考え方

歯肉構内から歯䅡部側約 $1 / 3$ までのカントゥアーを
Emergence Profile と呼んだ Stein, Kuwata らは, 一部 の例外を除き, sub-gingival contour を straight（直線的） にすることを推奨した。

Croll ${ }^{9,10)}$ は，天然歯を解剖学的な見地からと臨床的

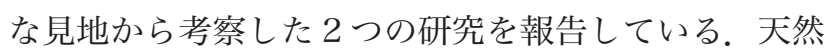
歯は, 解剖学的に僅かな例外を除き, straight な Emergence Profileを呈しており，臨床的な見地から， convex（凸状）の場合には，歯ブラシやトゥースピッ クなどの清掃器具が, 歯肉溝の中に十分到達しないため に, 歯垢が除去できないと述べ, クラウンは歯肉縁下で straight なカントゥアとなるよう作ることを主張した。

（2）sub-gingival contour を convex（凸状）にする 考元方

Wagman $^{11)}$, Kay $^{12)}$ は, 歯肉が厚い症例で, 歯肉縁下 のカントゥアが足りない場合には, 歯肉のサポートがで きず，辺縁歯肉はロール状になり歯肉の炎症を引き起こ すと述べており，実際の症例を提示している.

川島は臨床的な実験として, クラウンの唇煩側面形態 を，天然歯の正常な形態 (normal contour) とそれよ りも $0.5 \mathrm{~mm}$ 過豊隆を与えた過豊隆形態 (over contour) と $0.5 \mathrm{~mm}$ 小さくした豊隆不足形態 (under contour) の 3 種類について, 口腔内に仮着し, 歯垢沈 着を調査した ${ }^{13)}$ 。その結果, 歯肉縁上では, over contour は, under contour に比べて, 歯垢沈着率が有 意に大きかったが, 歯肉縁下においては, その逆に over contour は, under contourに比べて, 歯肉縁下の 深部において歯垢沈着率が有意に小さくなっていたと 報告している.

この研究結果は, Croll の述べた歯肉縁下で convex の形態は，十分な清掃ができず望ましくないという主張 と反対の結果となった。これは, Crollの主張が, 単に 理論的な考察であったためと筆者は考えている.

また，オーバーカントゥアの角度に関しての研究とし て，歯肉縁下においてノーマルカントゥア，30 度，50 度のクラウンを装着し, 臨床的にも微生物学的にもほと

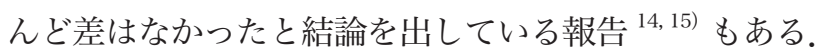
これは, 歯肉縁下の極端なオーバーカントゥアであって も, 歯肉に問題を起こすことはないことを示唆している. その他，実際のインプラント治療においては，以前よ り歯肉縁下で, 90 度に近いオーバーカントゥアの補綴

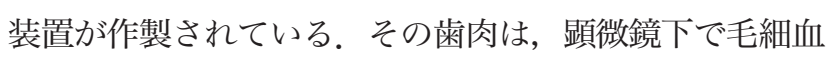
管の拡大などの像が観察されるものの, 重篤な炎症や骨 吸収が起きたという報告はない。その他にも，ハーフポ ンティックと称し, 隣接面下部のブラックトライアング ルをなくす目的で, 歯肉縁下部でかなり強いオーバーカ 
ントゥアを形作ることが頻繁に行われているが，そのた めに炎症を起こすことはないようである。

2) オベイトポンティックとの比較

BTA テクニックにおいて, 歯肉切除後, 歯肉の後戻 りを抑えるオーバーハングの形態をしたクラウンマー ジン部は，粘膜面を圧迫して作製するオベイトポン ティック ${ }^{16)}$ に類似している.

嶋倉は ${ }^{17}$ ) ポンティックの形態を, 自浄型, 接触型（無 圧で接触）, 圧迫型（軽い圧迫）に分けて，2週間口腔 内に仮着したブリッジのポンティック基底面の観察を 行った。 その結果, 自浄型, 接触型のポンティック基 底面には，全面にプラークの付着が認められたものが多 かったが，圧迫型のポンティックの場合には，基底面の 圧が加わっていない周囲のみにプラークが付着してい るものが多く観察された。これは，粘膜を圧迫している 部分では, 食物残渣などが圧入される間隙がないためで はないかと，嶋倉は考察をしている。

Nicola らは ${ }^{18)}$ オベイトポンティック型のブリッジを 12 力月間仮着し，ポンティックと接触した粘膜面の観 察を行った。 その結果, ポンティック基底面は僅かな量 のプラークが認められただけで，大部分の粘膜面には炎 症の兆候は認められなかった。顕微鏡下で, 粘膜を調べ ると, 粘膜の角質層の厚みは, コントロールとした何も 接触していない近接した咀嚼粘膜の角質層の厚みに比 べ $1 / 3$ 近くまで薄くなっていた. Nicola らは,このこ とについて機械的, 微生物学的侵襲に対する防御が弱く なったと述べている。

しかし,この点については,いちがいに防御が弱くなつ たと言うことはできないように思われる。粘膜が圧迫さ れることで，角質層が薄くなつた場合には，細胞間隙が 広くなり, 滲出液が漏出しやすくなり, ポンティックと 粘膜面の弥間を洗い流すことができる.滲出液の中には, 白血球，抗体，酵素などが入っており，免疫学的にも優 れている.

角化上皮という鎧を身に着け，ただ受身となって守り に入るのか, 鎧を捨て滲出液という武器を持ち, 侵入し てくる敵を攻撃することで守るのか，ということではな いかと考えている。

BTA テクニックにおいても，オベイトポンティック と同様に，オーバーハングの形態をしたクラウンマージ ンは，歯肉辺縁部を圧迫したような状態となり，クラウ ンマージンと歯肉辺縁の間の弥間がなくなり, 物理的に 歯垢の沈着，細菌の侵入を抑えられる.

そしてその隙間がなくなることは, 歯肉溝の深さ, 体 積が減ることになり, 滲出液の洗い流す力が強くなる可
能性がある. 滲出液の流出速度は, 約 $20 \mu \mathrm{l} / \mathrm{h}$ であり, 平均のポケット (歯肉溝) の体積は約 $0.5 \mu \mathrm{l}$ というこ となので, 1 時間に 40 回，入れ替わっているそうであ る ${ }^{19)}$. 歯肉溝の体積が減れば, より多くの回数入れ替 わることになり, 細菌などを洗い流す力や免疫能力が増 すのではないだろうか.

\section{3）歯肉辺縁部の厚み}

BTA テクニックにより歯肉切除を行った歯肉辺縁部 では，オーバーハングの形態をしたクラウンマージン部 が歯肉を抑えるために歯肉の厚みが厚く保たれる.

Maynard ${ }^{20)}$ は，歯槽骨と歯肉の厚みの違いにより 4 つに分類し, 厚い歯肉は, 薄い歯肉と比較して, 退縮し にくいことを報告しているが，今回提示した症例も，歯 肉退縮が起きた症例はなかった。

厚い歯肉では, 血流が良く, 細菌感染や歯肉退縮を防 止するために，有利な条件が作られるものと思われる。

4）歯肉縁部の自浄性，清掃性

南 ${ }^{21)}$ は, 歯冠と歯肉のなす形の側面に線をひいた 「カントゥアガイドライン」という桑田が名づけた基 準線 ${ }^{22)}$ からクラウンと歯肉の接合点までの距離が適 正（0.5 mm 以下）であるかどうかを, 観察し適正と なるようクラウンカントゥアを調整すべきであると述 べている。この距離が大きく離れている場合には，歯 肉とクラウンの境界部で窪みが大きくなり, 自浄性や 清掃性に問題が生じると症例を提示し説明している.

BTA テクニックでは, 歯肉切除した歯肉辺縁とほぼ 同じ厚みのオーバーハングの形をしたクラウンマージ ンが接する。 そのため, 歯肉とクラウンの境界部で, 篞 みが非常に少なくなり。歯ブラシによる清掃や口唇, 舌 による自浄作用で，歯垢を除去しやすくなることも，大 きな利点ではないかと考えられる。

\section{V. 有効性と利点}

以下にあげるように, 数々の有効性や利点があると考 える。

1. 歯肉ラインを整える（根尖方向に移動する）ため に，補綴的手法で行うことができる。

2. 電気入スを使用することで，簡便で正確な歯肉ラ インの形成ができ, 出血も少なく, 支台歯形成, 印象も同日に可能である.

3. 歯肉剥離も骨削除も必要ないため, 歯周組織への ダメージがたいへん少なく，アタッチメントロス も起きない，その上全体の治療期間が大幅に短縮 
できるとともに，患者への精神的，肉体的な負担 が少なくてすむ.

4. 舌側転移歯の歯並びを整える際には，根尖側に歯 肉ラインを移動すると同時に，唇側にも移動でき るため，唇側傾斜を防ぐことが可能である．当然， 舌側転移歯を抜歯してブリッジにする必要はない.

5. クラウンマージンで歯肉を抑えるため, 歯肉の後 戻りがなく審美性を保てる。

6. 歯肉辺縁部が厚くなるため血流も良くなり，骨吸 収や歯肉退縮が起きにくい生物学的に有利な環境 が作られる。

7. クラウンマージンの厚みが厚くなることで，色調 的にも強度的にも有利な条件となり, 歯質の削除 量は少なくてすむ。

8. 歯肉とクラウンの境界部の窪みが少なくなること で，歯ブラシによる清掃，口唇，煩粘膜による自 浄作用が有利となる。

\section{VI．結 論}

歯肉剥離や骨削除を伴う外科手術（歯冠延長術）を行 わずに，歯肉ラインを整える審美補綴法（BTA テクニッ ク）を開発し，以下の結論を得た。

1. BTA テクニックは，歯肉の切端方向への後戻りを防 止し，歯肉を健康に維持できることが長期的な経過 観察からわかった。

2. BTA テクニックは，技術的に簡便で，治療期間も大 幅に短縮でき，歯，歯肉ともに侵襲が少なく，患者 の肉体的，精神的，経済的負担も少なくできる.

\section{謝 辞}

稿を終わるに臨み，ご助言，ご指導を頂きました日本 大学歯学部歯科補経学第一講座の祇園白信仁教授，日本 大学歯学部解剖学第二講座の磯川桂太郎教授，上北沢歯 科の行田克則院長，クワタカレッジの桑田正博校長，東 京歯科大学病理学講座の下野正基教授，その他ご協力頂 きました諸先生に，深く感謝の意を表します。

\section{文献}

1) Robbins JW. Esthetic gingival recontouring--a plea for honesty. Quintessence Int 2000; 31: 553-556.

2) Ingber JS, Rose LF, Coslet JG. The "biologic width" -a concept in periodontics and restorative dentistry.
Alpha Omegan 1977; 70(3): 62-65.

3) Nevins M, Skurow HM. The intracrevicular restorative margin, the biologic width, and the maintenance of the gingival margin. Int. J Periodontics Restorative Dent 1984; 4(3): 30-49.

4) Sonick M. Esthetic crown lengthening for maxillary anterior teeth. Compend Contin Educ Dent 1997; 18: 807-812.

5) Lanning SK, Waldrop TC, Gunsolley JC, et al. Surgical crown lengthening: evaluation of the biologic width. J Periodontol 2003; 74: 468-474.

6) Yeh S, Andreana S. Crown lengthening: basic principles, indications, techniques and clinical case reports. NY State Dent J 2004; 70(8): 30-36.

7) Lazzara RJ, Porter SS. Platform switching: a new concept in implant dentistry for controlling postrestorative crestal bone levels. Int J Periodontics Restorative Dent 2006; 26(1): 9-17.

8）野澤 健，榎本紘昭，鶴巻春三ほか. 生物学的比率の 概念に基づくインプラント周囲のマネージメント。 インテッセンス・デンタル・インプラントロジー 2006; 13(2): 11-28.

9) Croll BM. Emergence profiles in natural tooth contour Part I: Photographic observations. J Prosthet Dent 1989; 62(1): 4-10.

10) Croll BM. Emergence profiles in natural tooth contour Part II: Clinical considerations. J Prosthet Dent 1990; 63(4): 374-379.

11) Wagman SS. The role of coronal contour in gingival health. J Prosthet Dent 1977; 37: 280-287.

12) Kay HB. Criteria for restorative contours in the altered periodontal environment. Int J Periodontics Restorative Dent 1985; 5(3): 42-63.

13）川島泰三. 天然歯打よび歯冠補綴装置の歯肉辺縁付近 における歯垢沈着について。補綴誌 1978; 22: 432-459.

14) Kohal RJ, Gerds T, Strub JR. Effect of different crown contours on periodontal health in dogs, Clinical results. J Dent 2003; 31: 407-413.

15) Kohal RJ, Pelz K, Strub JR. Effect of different crown contours on periodontal health in dogs, Microbiological results. J Dent 2004; 32: 153-159.

16）行田克則. ポンティックの形態と基底面下の粘膜につ いて 2）卵型の基底面を有するブリッジ・ポンティック の臨床応用. QE 1998; 17(1): 71-77.

17）嶋倉道朗. 橋義歯ポンティック基底面に付着するプラー クの観察。補綴誌 1976; 20: 465-481。

18) Nicola UZ, Carlo PM, Tord B. The ovate pontic design: histologic observation in humans. J Prosthet Dent 2002; 88(4): 375-380.

19）山本浩正. イラストで語るぺリオのためのバイオロジー 東京：クインテッセンス出版株式会社，2002, 66.

20) Maynard JG. Wilson RD. Diagnosis and management of mucogingival problems in children. Den Clin North 
Am 1980; 24: 683-703.

21）南 昌宏. 唇側クラウンカントゥア調整の基準. QE 2007; 26(1): 75-85.

22）桑田正博. 歯科技工別冊 Biological Crown Contour 一生体に調和する歯冠形態. 東京: 医歯薬出版株式会社, 2008, 40-41.
著者連絡先：坪田 健嗣

干 107-0052 東京都港区赤坂 7-5-34

インペリアル赤坂フォーラム 108

TEL : 03-3585-8519

FAX : 03-3585-8519

E-mail : kenji.tsubota@dream.com 


\title{
Development of an Esthetic Prosthetic Technique (the BTA Technique) for Aligning the Gingival Line
}

\author{
Kenji Tsubota, DDS, PhD
}

Ann Jpn Prosthodont Soc $2: 26-35,2010$

\section{ABSTRACT}

Purpose: The gingival line is very important for esthetic appearance. This paper describes a new prosthetic technique, the biological tissue adaptation (BTA) technique, to align the gingival line, without orthodontic treatment or surgical crown lengthening which require flap surgery and ostectomy, and maintains a healthy gingiva without rebounding over the long term.

Technique: The gingivectomy is performed with an electrocautery knife at the position of the gingival line taking into consideration both esthetic appearance and biologic width. In principle, the abutment tooth margin is prepared on the same line as the performed gingival line. In forming the prosthesis, the margin should be perpendicular at the surface of the tooth with the same thickness as the wounded gingival tissue. In other words, the shape of the prosthesis is overhanging the gingival tissue.

Discussion: All 17 cases maintained healthy gingiva without rebounding or other major complications. This appeared to be because the biologic width was reestablished in three dimensions, and plaque accumulation and bacterial invasion can be prevented, because the gingival tissue adapts tightly to the margin of the prosthesisformed overhang. In addition, the immune system may be superior because the bloodstream is not compromised due to the thick gingival margin, thus the periodontal surroundings biologically seemed to be preserved better.

Conclusion: The BTA technique has many advantages as a prosthetic technique in order to align the gingival line, and can maintain a healthy and esthetic gingiva over the long term.

\section{Key words}

gingival line, biologic width, gingivectomy, overhang, esthetics 